\title{
The role of group dynamics in creating a developing educational environment of a university
}

\author{
Irina Alexandrovna Povarenkina ${ }^{1 *}$, Natalia Hidarovna Frolova ${ }^{1}$, and Yulia Vladimirovna \\ Chicherina $^{1}$ \\ ${ }^{1}$ State Linguistics University of Nizhny Novgorod, Department of foreign languages, Institute of \\ Distance Learning, Nizhny Novgorod, Russia
}

\begin{abstract}
The transition to an individually-oriented educational paradigm and the freedom to choose individual learning trajectories leads to the underestimation of students' teamwork and group dynamics. The study addresses current issues in the implementation of team-building methods and technologies that have not been adequately addressed in the scientific didactic literature. Since at the present stage of its development society faces the need for specialists who able to positively and effectively adapt and interact in a work team, propose constructive ideas, and work in teams, more broad and diverse use of group forms of learning in the higher education system is needed. The article discloses the specifics of the group approach to education. Teamwork contributes to the development of personal and social and group growth and self-realization and strengthens value orientations in the formation of a humanistic worldview which, in turn, is aimed at the sustainable development of society. Such competencies include team competencies that involve the ability to solve interdisciplinary problems. The formation and development of such competencies take place in the context of teamwork. In the context of group dynamics, a student is responsible for reaching their own goals and shares the responsibility for achieving the goals of the team. A student team, in turn, is an environment where each of its members grows professionally and develops personally according to their individual trajectory of success. Theoretical analysis of group development and experimental education prove the effectiveness of group work. Group dynamics provide students with the opportunity not only to be creative but also to create a positive atmosphere and team spirit in the group.
\end{abstract}

Keywords: group dynamics, social learning, teamwork, team development.

\footnotetext{
*Corresponding author: povarenkinaia@mail.ru
} 


\section{Introduction}

The issue of the development of group dynamics in student groups gains special relevance since learning activities, being essentially individual, have little effect on the process of team building in the student academic group. The introduction of rating systems and the choice of individual learning trajectories entail the fact that the traditionally used educational technologies are not focused on the organization of joint activities, collective and group forms of learning.

The utilization of group dynamics as a technology of teamwork allows achieving a synergistic effect of combining collective efforts supported by group motivation, the unity of the group in terms of values and goals, and the solution of educational and professional problems.

\section{Methods}

Research and development of the issue of the didactic potential of group dynamics are reflected in numerous foreign and Russian studies.

The concept of group dynamics was first introduced by American psychologist K. Lewin in describing the processes taking place in a group, the dynamics of changes and continuity, the play of power in the group [1]. Later, D. Cartwright and E. Sander proposed their own definition referring to group dynamics as "a field of study devoted to expanding knowledge of the nature of the group, the laws of its development, and their impact on the individual, other groups, and larger organizations" [2,3].

The research of B. Tuckman reveals the stages of development of groups in the process of activity, social relations, and dynamic development of relations in the group. The scientific works of K. Michaelsen also substantiate the elements of learning associated with the team and offer an educational model created under the condition of humanistic relations within the group and cooperation and responsibility of each team member for the success of their comrades. The works of R. Slavin, S. Sharon, E. Aronson concern the special principles of teamwork aimed at identifying the social and didactic potential of this form of educational interaction [4-7].

\section{Results and discussion}

The analysis of research disclosing the didactic potential of group dynamics gives reason to believe that the use of such technology of educational interaction allows creating new conditions for effective learning in the transformation of modern higher education [8].

The modification of modern higher education consists in the change of its social function and the roles of participants in the higher education system. In the current situation, higher education has the opportunity to become an influential tool of society [9].

Under the conditions of transformation and the new context of higher education, the traditional format of the educational process - the study group - cannot be completely neglected. This form of educational interaction must remain an effective resource for students' development.

The American psychologist G. Allport originally believed that it was possible to fully predict the behavior of a group by knowing the characteristics of its individual members. However, according to K. Lewin's field theory, groups are something more than the sum of their components. Field theory is based on the principles of interaction suggesting that the behavior of people in a group is determined by the interaction of the individual with the environment. Lewin derived the following formula: $B=f(P, E)$, where the behavior $(B)$ of group members is a function (f) of the interaction of personality characteristics $(\mathrm{P})$ with the 
environment (E) including the characteristics of the group and members and the situation. $\mathrm{K}$. Lewin applied one of the concepts of Gestalt to the group - "the whole is greater than the sum of its parts", in the modern world this is referred to as the synergy effect. If the synergy effect is present in a group, it can achieve unpredictable results unattainable by a single person.

Researchers examining groups are convinced that groups have a significant influence on an individual as they shape their actions, thoughts, and feelings. Moving from a state of solitude to a group context reduces the awareness of one's uniqueness but, at the same time, increases a person's ability to perform simple tasks quickly.

Throughout the entire period of the study of group dynamics by foreign researchers, some approaches that seemed promising have been suspended or have not been further developed. Such approaches include the research of groupmind, syntality, groupality, and lifespace. Conversely, there are several topics that emerged at the beginning of the development of this area of research and are still studied by scholars in the present day.

There are various classifications of groups. Groups are divided into primary (family, friends) and secondary. Secondary groups are larger and more formally organized, their life span is shorter than that of primary groups, and there is less emotional connection within the group. A distinction between planned groups (created intentionally by its members or management) and suddenly created groups is also proposed. Planned groups are formed to perform a task and clearly know their composition and the criteria for inclusion in the group, work in such groups is based on regulations and official documents.

B. Lickel and colleagues conducted several studies asking the respondents to identify the groups they belonged to themselves. The conducted cluster analysis allowed the researchers to distinguish the following subcategories: groups with high intimacy, groups focused on completing the task, weak associations, and social categories [10].

All groups, along with their unique characteristics, have characteristics that are universal regardless of the size and origin of groups. These universal characteristics include interaction, interdependence, structure, cohesiveness, and goals.

Group interaction is as varied as human behavior, any type of behavior can be reproduced in a group context. After observing groups in different situations, R. Bales identified two main types of interaction most common in a group. Task interaction includes all types of group behavior focused on group work, projects, plans, and goals. In most groups, different skills, resources, and motivations have to be coordinated for the group to be able to make the right decision, create the product, and achieve its goal. Social and psychological interaction, unlike the first type, focuses on the interpersonal, social side of the group. If members of the group act indecisively and require support, other group members give them a lifeline, support them with kind words, and render various kinds of help. If there are disagreements in the group, they are accompanied by criticism of the group members. Such behavior does not contribute to performing the set tasks but promotes the maintenance of team members' emotional connections with the group.

The results, actions, thoughts, feelings, and experiences of some group members are partially due to the influence or interdependence of other group members. The success of the leader is determined by how well their subordinates perform. If the leader performed perfectly but their subordinates did not meet their assigned deadlines, the leader has also failed. In this case, members of the group share the responsibility among themselves and should help and assist each other. Interdependence consists in the fact that group members influence and are influenced by each other [11]. In the early twentieth century, Russian educator A.G. Rivin widely used the technology of self-study in pairs of shifting composition (PSC) [12]. A.G. Rivin's ideas formed the basis for the collective way of learning (CWL) later used by V.K. Diachenko [13]. 
Considering learning as a special case of communication, he distinguishes four forms of learning: individual, pair, group, and collective [13].

At the heart of the technology of collective learning are theories that characterize the collective work of students, namely:

- the socio-psychological theory relying on K. Lewin's research of group dynamics. The researcher argues that the essence of a group lies in the interaction of its members generated by the presence of a common goal. The life of a group is a dynamic whole where a change in the state of one member automatically entails a change in the states of all others [1];

- the cognitive theory based on the ideas of J. Piaget and L.S. Vygotsky on the development of human cognitive abilities. According to the developments of J. Piaget's school, the performance of joint activities is usually accompanied by the "sociocognitive conflict". The author believes that in the process of joint activity, participants engage in discussions that generate cognitive conflicts and stimulate their resolution. Real cognitive growth takes place only when children construct their own knowledge. According to L.S. Vygotsky, all knowledge is socially determined in nature and is generated by joint efforts in the course of understanding and resolving the arising problems [14].

- the behaviorist theory emphasizing group reinforcement and the final reward that motivates learning efforts.

Thus, according to the results of the analysis of research, we can hypothesize that students' involvement in collective mutual learning has a positive impact on their social and personal development and ultimately affects their success in mastering knowledge and developing skills, abilities, and competencies.

To clarify the modern understanding of group dynamics, we also consider the model proposed by Willan. According to his conception, there are five stages of group development.

At the first stage of development of the newly created group, its members find themselves in a state of dependency and inclusion. This stage is characterized by a high level of anxiety, insecurity, and politeness.

The second stage is the stage of counter dependency and fight. Conflicts arise at this stage as group members try to clarify and define their roles and disagreements arise over procedural issues in the work of the group. At this time, the structure of the group is only forming, there are power struggles, and the group is not yet able to use all of its resources to accomplish its tasks.

The third stage is the stage of trust and structure. Having passed the major pain points, the group begins a more mature process of discussing its goals, organizational structure, procedures, roles, and division of labor.

The fourth stage is titled work, in this phase, group members share information in a format that is convenient for them and clearly understand where, from whom, and how to obtain the necessary information.

The final fifth stage is characterized by a general awareness of the impending loss of group stability which can cause anxiety and even conflict. Conscious acceptance and management of these effects contribute to success in the work of subsequent groups. Unfortunately, this does not happen as often as it should.

\section{Conclusion}

The theories and concepts analyzed above substantiate the high potential of team interaction in the educational space [15: 32-64]. Unfortunately, traditional educational technologies do not conducive to this [16:109]

The purpose of group dynamics as a technology of teamwork is the formation of the communicative and social competencies, successful mastery of the content of the academic disciplines, and the development of communication competencies [17]. 
Thus, the organization of the educational process with the implementation of group dynamics as a technology of teamwork allows students to gain experience of collaborative creative teamwork necessary for their future professional activities.

\section{References}

1. K. Lewin, Dinamicheskaia psikhologiia: Izbrannye trudy [Dynamic psychology: selected works] (Smysl, Moscow, 2001)

2. D. Cartwright, The nature of cohesiveness, in Group dynamics, 89-94 (Evanston, Evanston, 1960)

3. Center for Strategic Research Human Capital. Ekspertnyi doklad "12 reshenii dlia novogo obrazovaniia" [Expert report "12 solutions for the new education"] (Higher School of Economics Publishing House, Moscow, 2018) Accessed on: December 9, 2020. [Online]. Available:

https://www.hse.ru/data/2018/04/06/1164671180/Doklad_obrazovanie_Web.pdf

4. D. R. Forsyth, Group dynamics (6th ed.) (Wadsworth Cengage Learning, Belmont, CA, 2014)

5. P. R. Laughlin, E. C. Hatch, J. S. Silver, L. Boh, Journal of Personality and Social Psychology, 90(4), 644-651 (2006). https://doi.org/10.1037/0022-3514.90.4.644

6. L. K. Michaelsen, A.B. Knight, L.D. Fink, Team-based learning: A transformative use of small groups in college teaching (Stylus Publishing, Sterling, 2004)

7. M.A. Qureshi, E. Stormyhr, International education studies, 5(2), 118-124 (2006) https://doi.org/10.5539/ies.v5n2p118

8. D. R. Forsyth, Group dynamics (6th ed.) (Wadsworth Cengage Learning, Belmont, CA, 2014)

9. V.V. Nikolina, Initsiativy XXI [Initiatives XXI], 1-2, 54-57 (2015)

https://doi.org/10.22363/2618-8163-2019-17-3-276-299

10. B. Lickel, D.L. Hamilton, G. Wieczorkowska, A. Lewis, S.J. Sherman, A.N. Uhles, Journal of Personality and Social Psychology, 78(2), 223-246 (2000). https://doi.org/10.1037/0022-3514.78.2.223

11. R.L. Krichevskii, E.M. Dubrovskaya, Socialnaya psikhologiia maloi gruppy [Social psychology of a small group] (Aspect Press, Moscow, 2001)

12. M.D. Breiterman, Metod A.G. Rivina. Na Putakh k Novoi Shkole [On the Way to the New School], 6, 14-21 (1994)

13. V.K. Diachenko, Kollektivnyi sposob obucheniia [The collective way of learning] (Narodnoie obrazovaniye, Moscow, 2004)

14. L.S. Vygotsky, Pedagogicheskaia psikhologiia [Pedagogical psychology], (Pedagogika, Moscow, 1991)

15. Ia. I. Kuzminov, B. L. Rudnik, I. D. Frumin, L. I. Iakobson, A. E. Volkov, I. M. Remorenko, Voprosy Obrazovaniia [Education Issues], 1, 32-64 (2008)

16. G.K. Selevko, Entsiklopediia obrazovatelnykh tekhnologii [Encyclopedia of educational technologies], Volume 1 (Narodnoye Obrazovaniye, Moscow, 2006). Accessed on: October 14, 2020. [Online]. Available: https://www.studmed.ru/view/selevko-gk-enciklopediya-obrazovatelnyh-tehnologiytom-1_2d66cc112d1.html

17. M. Shaw, Group dynamics: the psychology of small group behaviour (McGraw-Hill, New-York, 1976) 